DOI: http://dx.doi.org/10.21686/

2073-1051-2020-1-44-65

Социально-
эконмическе
проблемы

проблемы

\title{
Олег СУХАРЕВ
}

\section{ЭФФЕКТИВНОСТЬ НАУКОЕМКИХ ФИРМ И ФОРМИРОВАНИЕ ИННОВАЦИОННОЙ ДИНАМИКИ}

В России длительное время не удается сформировать инновационную модель экономического роста, поскольку меры в области стимулирования инноваций пока не позволяют перейти к данной модели развития. Одна из причин в том, что не учитываются региональные особенности инновационного развития, причем как на уровне разработки мер региональной политики в субъекте Федерации, так и на уровне фирм, функционирующих в данном регионе. В любом регионе России режим инновационной динамики уже сложился к текущему моменту, который характеризуется динамикой параметров инновационного развития, в частности темпом роста агентов-новаторов, изменением доли фирм-новаторов, т.е. наукоемких фирм. Текущая эффективность функционирования таких фирм влияет на их инновационные возможности, а также на численность агентов-новаторов в экономике. Исследование состояния инновационных возможностей на уровне фирмы, а также влияния массива новаторов в регионе может дать более рельефную картину возможностей проведения региональной политики инновационного роста. Для этого полезно изучение опыта других стран в сравнении с опытом отечественным. Так, анализ результатов инновационной динамики позволил установить, что, например, в России в отличие от США, Китая, ЕС увеличение ВВП происходило одновременно с сокращением числа агентов-новаторов и доли фирм-новаторов. Темп роста снижался при увеличении темпа роста числа агентов-новаторов на изучаемом интервале времени. Это типично консервативная модель экономической динамики. Инновационная модель развития предполагает ситуацию, когда ВВП увеличивается с ростом числа агентов-новаторов, темп роста замедляется с увеличением темпа роста числа агентов-новаторов в силу достаточно высокой доли этих агентов от общего числа, ито характерно для Китая. Тем самым формирование инновационной модели роста российской экономики потребует изменений в правительственной системе мер экономической политики, включая учет мер избирательно на уровне каждого из ее регионов, причем аспект инновационного процесса на микроуровне (на уровне наукоемкой фирмы) требует особого внимания. Чтобы стимулировать инновационное развитие, понадобятся такие воздействия, которые бы изменили закон связи динамики ВВП и числа фирм и агентов-новаторов. Кроме того, понадобится создать условия для перемещения трудового ресурса от старых к новым производствам, подготовку кадров для новых производств, учитывать ограничения по эффективности наукоемких фирм, действующих в регионе, вводить стимулирующий налоговый механизм, демпфировать риски ввода инноваций и др. 
Ключевые слова: инновации, показатели инновационной динамики, регион, рост валового внутреннего продукта, фирмы-консерваторы, фирмы-новаторы, эффективность наукоемких организаций

JEL: C51, O30, O41, O51, O52

Процесс инновационной модернизации региональных экономик невозможен без запуска инновационных процессов хозяйствующими субъектами. Региональные власти способны оказать в решении этой задачи известную поддержку. Однако для этого они должны понимать, когда и при каких условиях начинается инновационная модернизация фирм, какая сложилась связь между экономическим ростом в регионе и появлением новаторов в нем. Это позволит подчинить региональные инструменты воздействия на экономику конкретным задачам стимулирования инновационного развития в регионе.

Проводимый ниже анализ может быть применен для исследования отдельных регионов, разработки мер по формированию стратегии инновационного развития российских регионов, учитывающей аспекты изменения числа новаторов, как агентов, так и фирм, что определяется условиями, возникшими в конкретных регионах России.

\section{Общие особенности современного инновационного развития}

Современное инновационное развитие характеризуется большим динамизмом, внося существенную лепту в экономический рост и увеличение благосостояния. Оно формируется благодаря взаимодействию, конкуренции новаторов и консерваторов ${ }^{1}$.

Инновации не только могут способствовать росту, но и приводить к кризису на уровне как отдельной фирмы, их реализующей, так и страны в целом. Причина в том, что внедрение инновации определяется тем, насколько элементы системы восприимчивы к этому новому результату, справляются с увеличением издержек, сопровождающих процесс ввода инновации, что приводит к повышательной динамике цены [1; 2]. При этом прибыль на первых этапах «эксплуатации» инновации не является высокой, так что классический показатель эффективности может сначала понизиться.

Далее возможны две траектории движения.

Развитие по первой траектории движения сопровождается в дальнейшем ростом эффективности в силу повышения прибыли и снижения роста затрат. Вторая траектория связана с вмешательством неких факторов рыночного или технологического свойства либо институциональных коррекций, осуществляемых правительством, что не позволяет переориентировать рынок на осуществляемую инновацию и получить рост эффективности.

${ }^{1}$ Если новатор выступает генератором появления новизны в различных сферах деятельности, будь то продукты, технологии, процессы, услуги, организация и управление, то консерватор ориентируется на уже применяющиеся методы, процедуры, рутины, технологии, рынки, продукты, допуская лишь незначительные изменения, не провоцируя и не генерирую новизну. 
В итоге фирма откажется от дальнейшей реализации инновации и перейдет к прежним позициям, которые имела до ее ввода. Либо будет пробовать иные инновационные возможности, если такую стратегию позволяют реализовать имеющиеся у нее ресурсы. Обычно низкая эффективность инноваций задается текущим состоянием фирм, имеющимся потенциалом для реализации инноваций и инновационного поведения, сформировавшимися рынками, где действует фирма, уровнем ее наукоемкости ${ }^{2}$ и технологичности, динамически изменяемыми ограничениями деятельности, включая налоговые изменения. Именно низкая эффективность инноваций по причине высоких затрат и ограниченности авансового капитала, рыночных ограничений на приобретение инновационных изделий становится блокатором инновационного развития, переориентируя агентскую модель на консервативные предпочтения. Они могут оказаться с позиции общей эффективности функционирования на рассматриваемом интервале времени более приемлемыми. Эффективность инноваций различных типов отличается во времени.

Например, эффективность фундаментальных инноваций на относительно коротком интервале времени будет равна нулю, но долгосрочная эффективность может оказаться высокой. Продуктовые инновации, а также улучшающие и имитирующие, наоборот, на коротком и среднем интервале времени покажут не низкую эффективность, однако в долгосрочном периоде их эффективность отсутствует, т.к. эти инновации длительно не осуществляются в принципе. Чем больше размер капитала (размер фирмы), тем для одной и той же величины неприятия риска инновации полезность от инновации при прочих равных будет обычно выше. К тому же размер фирмы по капиталу позволяет осуществлять наиболее капиталоемкие инновации, ближе к инновациям фундаментального типа.

С одной стороны, это требование программируется усложнением науки и исследовательских изысканий, с другой - величиной затрат труда и требующегося нового оборудования, а также возможностями инвестировать новые изыскания. Следовательно, фирмы малого размера могут добиваться неких результатов только на отдельных направлениях исследований, причем масштаб этих инноваций ограничен размерами фирмы. В связи с этим инновационным (наукоемким) фирмам малого размера требуется дальнейшее тиражирование полученных результатов. Это касается фирм, занимающихся исключительно опытным производством

2 Под наукоемкостью фирмы можно понимать величину НИОКР, проводимых на фирме в общей величине затрат или объемов производства этой фирмы. Это будет текущая величина наукоемкости. Общая наукоемкость или научно-технический потенциал фирмы - это оценка всего накопленного интеллектуального капитала, технологических заделов, охватываемых патентной базой, образцами полезных моделей, авторскими свидетельствами, архивной технической документацией и технологическим опытом решения различных научно-технических задач. Можно оценить этот уровень по доле образованного кадрового состава фирмы с определенным уровнем образования, оцениваемым по введенной шкале. Последний подход широко применяется для оценки наукоемкости (знаниеемкого производства), в частности за рубежом, например Евростатом. В данном исследовании под фирмой-новатором и наукоемкой фирмой понимается по существо одна и та же фирма. 
и/или осуществляющих НИОКР. Крупные фирмы, располагающие отдельными подразделениями, ведущими научно-исследовательские и опытно-конструкторские разработки, обладают мощностями для тиражирования полученных результатов и внедрения их в производство.

В России имеется одно важное свойство организации наукоемкого сектора - это предметная специализация, позволившая сохранить многие ценные технологии в оборонном секторе. Те фирмы, которые прошли приватизацию и свернули замкнутый цикл производства либо он был нарушен по иным причинам, ориентировались на предметную специализацию, но ее отсутствие на таких рынках, в т.ч. вследствие образовавшихся многочисленных технологических разрывов, привело к потери таких производств. В связи с этими процессами многие имеющие место закономерности на рынках наукоемкой продукции западных стран не находят подтверждения в России [3; 4].

Рассмотрим подробнее проблему эффективности наукоемких фирм на уровне базового критерия эффективности и его изменения, а также проведем анализ инновационной динамики российской экономики по числу агентов и фирм-новаторов, выявив влияние инновационной модели на экономическое развитие.

\section{Ограничение для инноваций на микроуровне}

Если под новаторами рассматриваются агенты, занимающиеся профессионально созданием новых знаний, продуктов, процессов, методов и систем, а также управлением соответствующими проектами $[5 ; 6 ; 7 ; 8]$, то под фирмами-новаторами, согласно указанным источникам, понимают инноващионные предприятия, создающие новые продукты и услуги, хотя бы для отдельных потребителей. Тем самым эти продукты и услуги не производятся иными фирмами, либо число таких фирм, создающих такие же продукты, весьма ограниченно. Разница между общим числом агентов, фирм и агентами-новаторами либо фирмами-новаторами составляет соответственно число агентов-консерваторов и фирм, реализующих консервативную модель поведения, т.е. отстаивающих уже оформленные рыночные позиции, продукты, уже применяющиеся технологии (старые технологии) и использующих уже известные формы организации бизнеса и производства.

Фирма, внедряющая новацию, создающая новизну, осуществляющая НИОКР, использующая ее результаты либо продающая эти результаты иным фирмам для применения, располагающая образованным и профессиональным кадровым составом, способным создавать новизну, может быть обозначена как наукоемкая фирма. Иными словами, она применяет результаты, полученные в ходе исследовательской, поисковой работы как особого вида труда, развернутого и оплачиваемого на этой фирме, обеспеченного фондами - лабораторной и экспериментальной базой. Нужно отметить, что с позиции учета таких фирм, конечно, присутствует весьма условный критерий, выражающийся в установлении некоей доли проводимых НИОКР от общего объема производства либо числа занятых, имеющих некоторый уровень об- 
разования. Однако и крупный машиностроительный гигант, производящий грузовые автомобили, располагающий собственным опытным, экспериментальным производством, лабораториями и конструкторским бюро, может с позиции некоего критерия быть не отнесен к наукоемкому производству, но на самом деле представляет именно такой вид производства, базирующийся исключительно на осуществленных прикладных научных изысканиях, достижениях инженерной науки. При этом решаются важнейшие научные инженерные задачи обеспечения устойчивости динамики движения транспортного средства, надежности, износостойкости, долговечности или поверхностной прочности его деталей, узлов, агрегатов и т.д. Совершаемые рационализаторские предложения, изобретения составляют содержание и результат поисковой работы в области осуществления инженерных решений. Фирмы, проводящие такую работу либо сугубо занимающиеся разработками и НИОКР, представляют собой наукоемкие предприятия. Эффективность их функционирования отличается от эффективности серийных производств, т.к. в последнем случае она зависит от сбыта продукции, полученной выручки, прибыли и понесенных затрат. Однако в области интеллектуального труда и научных исследований принципиально отсутствует серия и часто даже производственный результат. Объектом продажи выступает отчет по НИОКР либо полезная модель, опытный образец, причем зачастую изготавливаемые в единичном экземпляре или партией, насчитывающей буквально несколько штук. Конечно, классическое представление об эффективности в таких работах присутствует, поскольку продажная цена сопоставляется с понесенными затратами, причем она должна быть выше затрат, чтобы проект был признан эффективным, т.е. поисковая работа должна окупить затраты.

Вместе с тем существует принципиальная разница между фирмами, специализирующимися в основном на проведении НИОКР и создании изделий сверхмалых серий (в штучном экземпляре), и фирмами, которые сами же внедряют свои результаты НИОКР в серийном собственном производстве. Они также могут быть отнесены к наукоемким фирмам при соответствующей доле НИОКР от общего производимого объема. При наличии серийных производств, получаемая прибыль, зависящая от ситуации на рынке этой продукции, тем не менее позволяет финансировать самостоятельно поисковую работу за счет собственных средств либо привлеченных (кредит будет погашен из полученной прибыли). Если же специализация фирмы - сугубо научные поисковые работы, проведение опытно-конструкторских работ, то в этом случае не приходится рассчитывать на большую прибыль, особенно если фирма не является монополистом в проектных работах. Более того, финансовая устойчивость фирмы при указанной специализации зависит от портфеля проводимых поисковых работ, причем некоторая доля от проводимых НИОКР может завершаться отрицательным результатом.

В итоге такие НИОКРы продаются по самой низкой цене или дальнейшее их осуществление прерывается на промежуточных этапах, но совершенные затраты не окупаются. Как видим, это весьма специфическая 
деятельность, которая также зависит от состояния рынка продукции в рамках таких направлений как НИОКР и поисковая работа в рамках отраслевых исследований. Очень часто экономисты-исследователи не принимают во внимание тот факт, что часть НИОКР заканчивается отрицательным результатом и не окупается. Это одна из причин, почему крупные фирмы, корпорации содержат исследовательские лаборатории, т.к. располагают необходимыми финансовыми ресурсами и потребностью использовать получаемое новое знание в конкурентной борьбе на рынке. Деятельность малых наукоемких фирм, занимающихся разработкой технических систем, ограничена размером того направления инженерной сферы, на котором они специализируются, причем это может быть довольно узкая специализация. Эффект узкой специализации обеспечивает монополистические позиции на соответствующем рынке наукоемкой продукции и проведения прикладных исследований и разработок. Это позволяет окупать затраты на проводимые изыскания, частично перенаправляя средства на те работы, которые менее успешны и не дали положительных результатов, но потребовали затрат. Тем самым в рамках портфеля заказов происходит распределение ресурсов даже на малой фирме. Поэтому формирование такого портфеля, а также диверсификация поисковой работы и проводимых разработок представляет центральное направление в работе подобных наукоемких фирм, обеспечивающих им эффективное функционирование. Значит региональная экономическая политика должна включать инструменты, обеспечивающие формирование именно таких портфелей заказов для конкретных фирм по секторам региональной экономики.

В классическом смысле эффективность $(E)$ наукоемкой фирмы определяется как отношение разницы цены $(P)$ продаваемого наукоемкого результата (НИОКР) и затрат $(Z)$, пошедших на его получение, к величине этих затрат.

Это записывается в виде: $E=(P-Z) / Z$.

Для фирмы нужен рост эффективности или по крайне мере не снижение величины эффективности, т.е. $d E / d t \geq 0$. Представим цену $P=w+m+f+n$, где $w$ - заработная плата, $m$ - материальные затраты, $f$ - прибыль, $n-$ величина налогов, а общие затраты $Z=w+m$. Тогда получим $E=(f+n) / Z$. Затем, найдя $d E / d t \geq 0$, несложно найти, что

$$
g_{Z} \leq\left(f g_{f}+n g_{n}\right) /(f+n),
$$

где $g_{Z}=(1 / Z) d Z / d t ; g_{f}=(1 / f) d f / d t ; g_{n}=(1 / n) d n / d t-$ соответственно, темп роста общих затрат, прибыли, величины налогов.

Отсюда можно переписать условие для роста или несокращения эффективности фирмы: $g_{f} \geq g_{Z}(1+n / f)-n g_{n} / f$. При этом $g_{Z}>g_{n}$. Если $g_{f}>g_{Z}$, то для роста эффективности $g_{n}>g_{Z}$. Коэффициент прибыльности и эффективность буду возрастать. Поскольку для наукоемких фирм $g_{Z}>0$, то и $g_{n}>0$, т.е. налоги могут возрасти, и это в рамках данного режима не приведет к понижению эффективности. Важно лишь определить допустимый диапазон повышения, а также учесть нелинейные связи влияния этого повышения на саму прибыль, затраты и их изменение. Эти аспекты в приведенных выше выкладках не учитываются. 
Таким образом, чтобы эффективность росла или по крайне мере не уменьшалась, темп роста прибыли должен быть больше или равен разнице взвешенного темпа роста затрат и взвешенного темпа роста налогов. Чтобы коэффициент прибыльности фирмы рос, а именно $u=f / Z$, $d u / d t>0$, достаточно, чтобы темп роста прибыли был выше темпа роста затрат. Обычно наукоемкие фирмы характеризуются ростом затрат, поскольку новые результаты требуют значительных усилий, издержек на поиск информации и проведение исследований. Только на следующих этапах их применения удельные издержки могут понизиться. Однако для получения этих результатов издержки, как правило, возрастают ${ }^{3}$.

Из полученного выражения для роста эффективности следует, что темп роста налогов может стать отрицательным, налоги снижаются, но величина налога $n$ при этом может возрасти. В таком случае при том же темпе роста затрат, чтобы росла эффективность наукоемкой фирмы, темп роста прибыли должен быть выше. Тем самым даже снижение налоговой ставки не во всех случаях может облегчить условия инновационного развития. Повышение ставки налога (положительный темп роста) может даже понизить ограничение на темп роста прибыли, чтобы эффективность возрастала. Следовательно, выбор налоговой системы и даже изменение ставок налогов является, в общем-то, с инструментальной точки зрения весьма тонкой операцией в рамках стимулирующей инновационное развитие экономической политики, что видно даже при осуществлении элементарных аналитических выкладок.

В реальности ситуация много сложнее, поскольку при изменении налогов наверняка изменяются затраты, зависящие от этого изменения, и величина прибыли. Снижение налогов, как ни парадоксально, может не способствовать инновационному развитию, а повышение налогов делает это развитие слишком дорогим, и, тем самым, также локализует и рынок, и возможности инновационной динамики. Конечно, следует учитывать, что понижение налогов видимо позитивно скажется на консервативной модели поведения агентов, что, в конечном итоге, создает в будущем предпосылку для развертывания инноваций, превращения консерваторов в новаторов. Хотя такой результат также не является заданным и столь тривиальным. С ростом налогов затраты могут возрасти, прибыли понизиться. Это будет действовать в направлении понижения коэффициента прибыльности. Общий результат по эффективности будет зависеть от чувствительности этих параметров к изменению налогов. Конечно, налоги представляют собой очень сложный инструмент влияния, инерционный, что может смазать силу их воздействий, потому что с течением времени изменяется сама чувствительность, зависящая от многих институциональных факторов.

${ }^{3}$ Хотя имеется исключение, когда действует и весьма сильно так называемый «комбинаторный эффект», благодаря которому новое знание, технология возникают без больших затрат посредством соединения уже известного и имеюшегося на фирме знания. Это эффект получает все большее распространение, однако он пока не имеет настолько тотального влияния, чтобы изменить общую сложившуюся тенденцию роста затрат при получении нового знания и новых поисковых результатов. 
Если темп роста зависит от числа новаторов $g=f(N)$, а появление новаторов определяется средней величиной эффективности либо соотношением средней эффективности уже действующих новаторов и консерваторов $\left(E_{N} / E_{K}\right)$, т.е. $N=h\left(E_{N} / E_{K}\right)$, тогда $g=f\left(h\left(E_{N} / E_{K}\right)\right)$. Тем самым темп роста экономики определится соотношением эффективности функционирования фирм-новаторов и консерваторов. Уровень монополизма во всяком случае будет влиять на величину эффективности функционирования новаторов. Связь этих параметров может оказаться довольно тесной. Проблема связи эффективности новатора и консерватора более сложная, поскольку одна и та же фирма или агент могут на одном интервале времени реализовывать новации и считаться новаторами, на другом отрезке времени - консерваторами, ориентироваться на сложившиеся продукты и рынки без реализации новаций. В обоих случаях эффективность может отличаться, а может оказаться довольно близкой по значению. Это зависит от множества условий и факторов, детерминирующих конкретные типы решений на фирме. Новый новатор имеет определенные трудности в появлении, и одна из них связана как раз с противодействием сложившегося монополизма уже действующих новаторов.

Значительных затрат требует преодоление монополизма уже действующих фирм в сфере НИОКР и наукоемкой деятельности, разработки средств производства, специальной технологии, приборов. Обычно выход на такой рынок предполагает преодоление самого сильного барьера наличия технологического знания, имеющегося в распоряжении уже действующих фирм. В отдельных работах полагают, что это конкурентное преимущество по располагаемому знанию является временным, а системные условия могут оказаться много сильнее [9]. Новое знание и его применение должно дать наиболее выгодный результат, причем и с точки зрения критериев «затраты-цена» и «цена-качество». Это становится дополнительным ограничением на развитие конкуренции на рынке НИОКР и поисковой работы. Научная работа, открытое новое знание и новизна как таковая формируют монополию. Если появилось что-то новое, значит, равнозначного объекта до сих пор не существовало, либо сушествовало что-то похожее, но все-таки иного содержания, возможно, иного смысла или применения. Следовательно, новизна во многом определяет структуру рынка НИОКР и поисковой работы, закрепляет позиции наукоемких фирм, определяя конкуренцию между ними, напрямую влияя на появление новых инновационных фирм․

Однако, если осуществлено что-то новое, то, что до сих пор не существовало, тогда говорить о монополизме по данному благу преждевременно, ведь осуществляется выход на рынок того, что уже существует и делается. С одной стороны, такое возражение верно - для абсолютно нового результата рынок является открытым, т.е. не существовавшим ранее, с другой - новизна предполагает знание определенного типа, например технологическое знание. Рынок технологического

${ }^{4}$ В данном случае «наукоемкая фирм» и «инновационная фирма» или фирма-новатор понимаются равнозначно, поскольку в современном мире различные виды инноваций в подавляющей степени определяются полученными научными результатами. 
знания существует, другое дело, что различные технологии по своему содержанию присутствуют на таком рынке, но выбор технологии также предполагает наличие критерия выбора, сравнения применяющихся и новых технологий либо оценку новых технологий, если их не с чем сравнить и они созданы впервые.

Если в экономике существуют технологические разрывы в производственных контурах, низкий уровень технологичности по многим видам производства соседствует с отдельными высокотехнологичными производствами, порождая «технологическую диспропорцию», то это становится ограничителем инновационного развития, по крайней мере по технологическим инновациям. Одновременно ограничиваются и другие типы инноваций в области управления и организации процессов и т.д. Существующие проблемы извлечения прибыли даже на классических рынках продукции и услуг ограничивают прибыль по новым видам деятельности, причем это ограничение тем острее, чем ниже динамика роста реальных располагаемых доходов населения, большая часть которых формируется именно на базе консервативных видов деятельности. Поэтому не является фактом, что переключение на абсолютно новые технологии в такой системе возможно и целесообразно при наличии инерции негативного развития консервативных фирм, в частности снижения эффективности их функционирования. Еще немаловажный момент - эффективность функционирования можно обеспечить, как раз отказавшись от инновационной деятельности, причем с малым риском.

Инновационная деятельность обычно характеризуется среднеили долгосрочной отдачей (конечно, это зависит от типа инновации) в отличие от консервативной модели поведения, ориентирующейся на текущий результат. Оптимальная стратегия развития - это планомерный переход на улучшающие консервативную деятельность технологии, дающие экономию и повышающие прибыль, следовательно, и эффективность функционирования. В данном случае параллельно с ростом эффективности увеличиваются мотивы для дальнейших улучшений (инновации улучшающего типа), синергия которых со временем может резко повысить качество производства и потенциал его дальнейшего развития.

Масштаб новых результатов и число фирм-новаторов не может не влиять на экономическую динамику. По всей видимости, поскольку новые результаты и по масштабу, и по структуре и качеству отличаются, то и влияние на динамику ВВП как этих результатов, так и числа фирмноваторов, а также агентов-новаторов будет различным [10].

Это предположение проверим далее на эмпирическом материале российской экономики, сопоставляя ее инновационную динамику с некоторыми странами, лидирующими в области инноваций и наукоемкого развития (США, Китай, Европейский союз). Оценим динамику ВВП и сопровождающее ее изменение числа агентов и фирм-новаторов. Сначала оформим общий подход к оценке инновационной динамики, характер которой зависим от сложившейся модели изменения эффективности функционирования наукоемких фирм (фирм-новаторов), 
влияющей и на число вновь появляющихся этих фирм, и на процесс их исчезновения из хозяйственной системы. Этот процесс происходит в т.ч. за счет перехода к консервативной модели поведения, обеспечивающей меньшую величину риска и приемлемую эффективность функционирования. Затем осуществим эмпирические оценки указанных параметров по следующим странам: Россия, Китай, США и Европейский союз, т.К. именно эти субъекты мировой экономики существенно влияют на процессы мирового развития и конкуренции, особенно в инновациях и технологической сфере.

\section{Анализ инновационной динамики: макроэкономический уровень}

Инновационная динамика довольно изменчива по причине значительного числа внедряемых новых комбинаций, часто непредсказуемым образом взаимодействующих между собой.

Изменение инноваций различных типов определяет динамику инновационного развития. В связи с этим важен структурный анализ инноваций [11; 12; 13], позволяющий показать влияние на динамику инновационного развития инноваций определенного типа, а также оценить их вклад в темп экономического роста страны. В этом и состоит эффект влияния инноваций, по крайней мере выраженный в текущей оценке. Помимо текущего эффекта динамики имеется, безусловно, некий кумулятивный эффект. Однако его оценка требует более выверенных подходов и всегда является дискуссионной по причине существования различных взглядов на эту проблему измерения и оценки кумулятивного или синергетического влияния инновационных результатов.

В связи с тем, что параметры инновационной динамики изменяются по причине действия различных факторов, их влияние на экономический рост, включая его темп, также перманентно изменяется. Поэтому далеко не всегда экономический рост поддерживается инновационной динамикой, т.к. консервативная модель на уровне агентов и фирм может обеспечивать в какой-то период времени довольно устойчивую динамику валового внутреннего продукта.

Инновационная динамика определяется несколькими важными параметрами, изменяющимися во времени. К ним можно отнести следующие:

1) число инноваций и их структуру (по Й. Шумпетеру, пять типов инноваций - новых комбинаций $[14 ; 15 ; 16]$; или, согласно системе российского учета, - технологические, продуктовые, процессные, организационные и маркетинговые инновации либо фундаментальные, технологические, в виде усовершенствования, продуктовые, имитирующие $)^{5}$;

2) число агентов-новаторов и консерваторов, а также имитаторов, которые занимаются тиражированием уже введенной инновации;

5 Каждая классификация имеет свое назначение и может использоваться в анализе инновационной динамики с позиции оценки веса каждого типа в общей структуре инновационных результатов, вклада в общую инновационную динамику и темп роста ВВП страны. 
3) число фирм-новаторов и фирм-консерваторов, влияющих на динамику валового внутреннего продукта;

4) число новых и старых технологий и соответствующих им новаторов и консерваторов;

5) соотношение темпа роста ВВП и темпа роста фирм-новаторов или темпа числа новаторов в стране;

6) изменение общей технологичности экономики и ее подсистем секторов по соотношению объема производства на новых и старых технологиях (при отсутствии данных по производству на новых и старых технологиях в расчете может применяться величина отгруженной продукции, изготовленной на новых и старых технологиях, определенная по соответствующим статьям ОКВЭД).

На рисунках 1-2 показана динамика числа фирм-консерваторов и новаторов.

В Китае число фирм-консерваторов и новаторов существенно увеличивается, причем, если разница между числом этих фирм была примерно в шесть раз в пользу консерваторов, то стала примерно в 3 раза, т.е. сократилась за счет опережающего увеличения числа фирм-новаторов. В России число фирм-консерваторов несколько возрастает, но число фирм-новаторов довольно интенсивно убывает, являясь незначительным, более чем в десяток раз меньше числа фирм-консерваторов. США имеют второе после Китая число фирм-новаторов и меньшее, чем в России, число фирм-консерваторов. Германия и Япония имеют примерно стабильную структуру, задаваемую числом фирм-новаторов и консерваторов с превышением последних в 1,5-3 раза. Вместе с тем число фирм-новаторов всех рассмотренных стран превосходит число фирм-новаторов в России, причем для США, Китая и Японии довольно существенно.

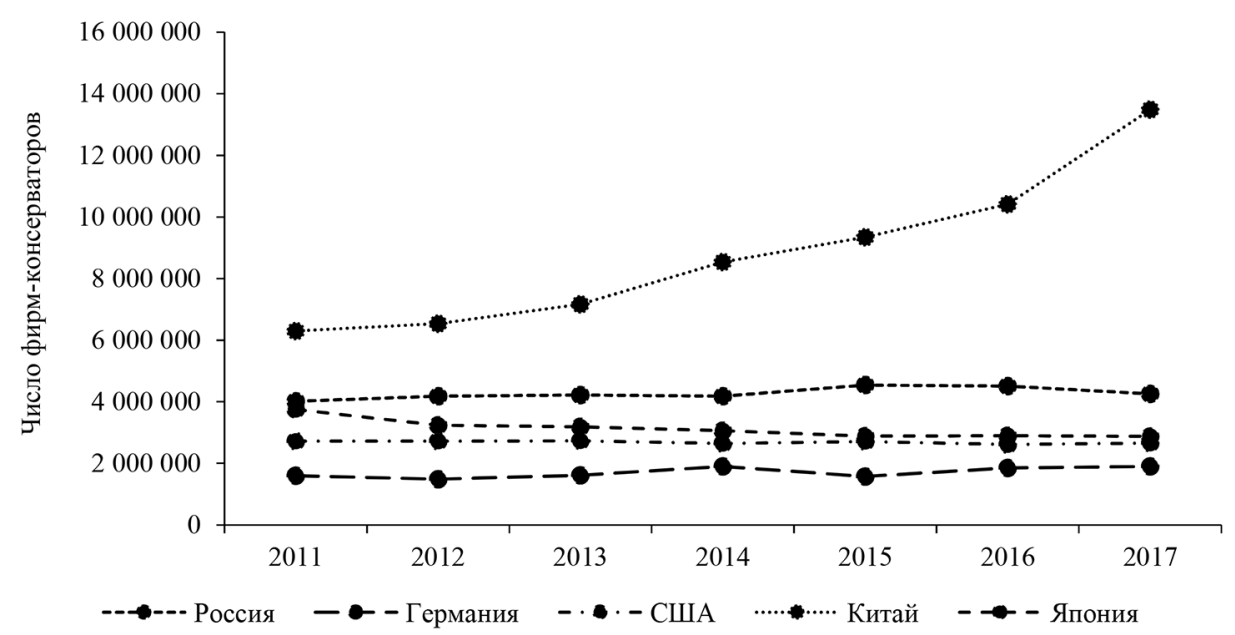

Рис. 1. Число фирм-консерваторов в некоторых странах, 2011-2017 г2.

Источник: составлено автором по [5; 6; 7]. 


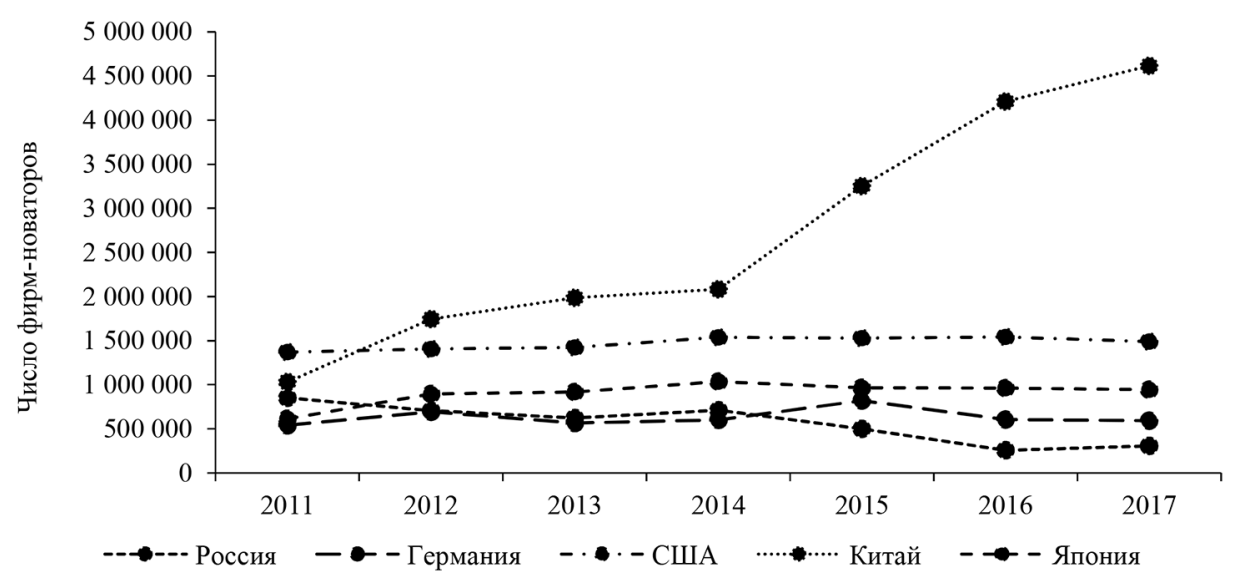

Рис 2. Число фирм-новаторов в некоторых странах, 2011-2017 г2.

Источник: составлено автором по [5; 6; 7].

Подобранные эконометрические модели связи ВВП и численности новаторов в России, Китае, США (см. рис. 3-6) ${ }^{6}$, по эмпирическим данным по странам, включая Европейский союз (см. рис. 6), подтверждают, что увеличение валового внутреннего продукта, рассмотренного в ценах 2010 г., сопровождалось ростом числа агентов-новаторов в Китае, США, ЕС. В России наблюдался обратный процесс, согласно которому увеличение ВВП происходило одновременно со снижением числа агентов-новаторов. Из рисунка 2 видно, что и число фирм-новаторов также сокращалось в России.

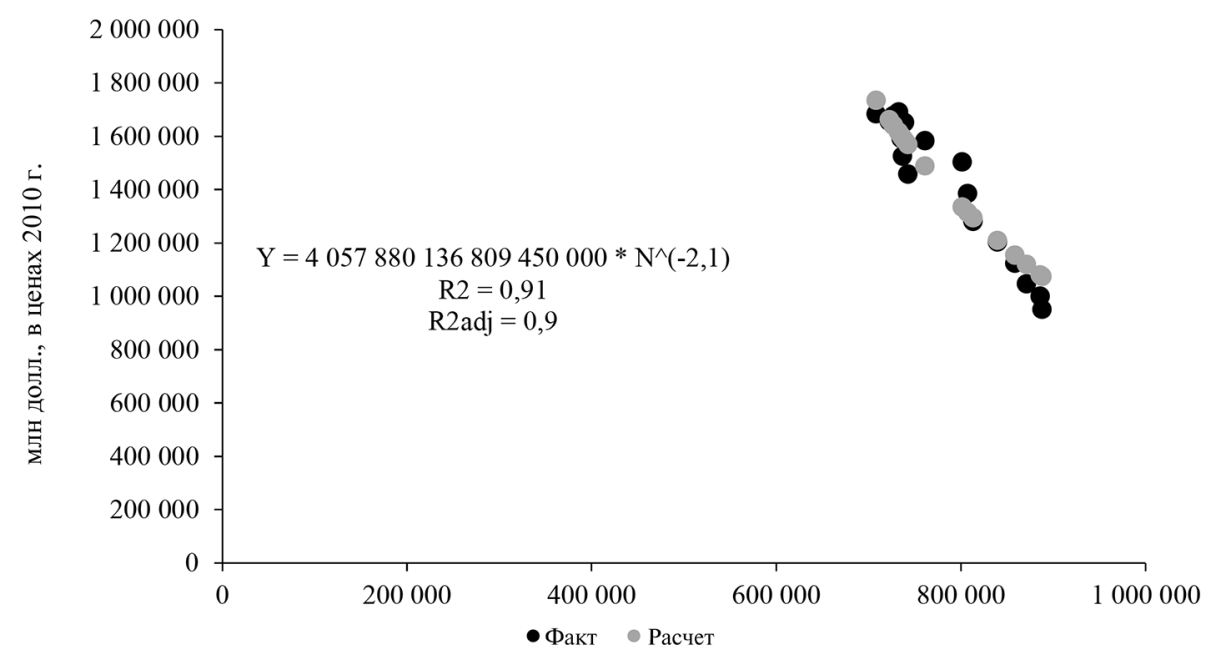

Рис. 3. Валовой внутренний продукт России и численность новаторов, 2000-2017 z2.*

Источник: составлено автором по [5; 8].

* Статистики модели: $F$-критерий $=41,3, D$-Wрасчет. $=1,8 \in[1,39 ; 2,61]$, тест Уайта: $\chi 2$ расчет. $=1,27, \chi 2$ крит. $=3,84$.

${ }^{6}$ В проведении расчетов (см. рис. 2-6) приняла активное участие канд. экон. наук Е.Н. Ворончихина, за что автор выражает ей большую благодарность. 


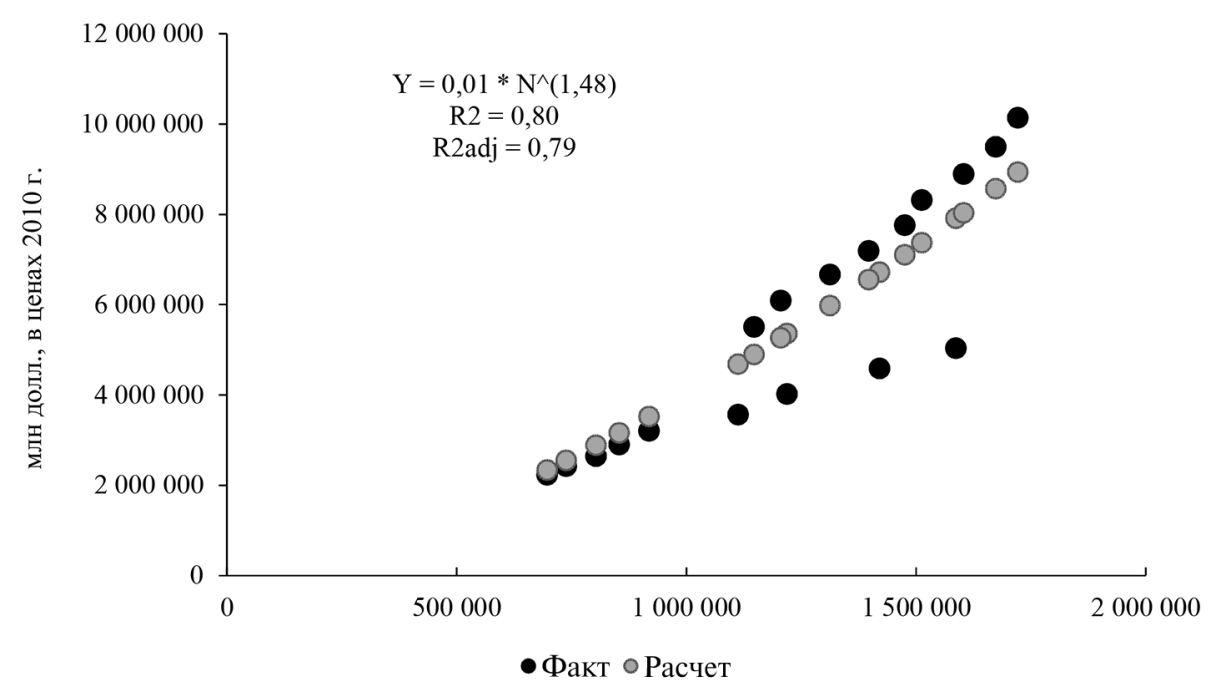

Рис.4. Валовой внутренний продукт Китая и численность новаторов, $2000-2017$ г2.*

Источник: составлено автором по [5; 8].

* Статистики модели: $F$-критерий $=55,8, D$-Wрасчет. $=1,5 €[1,39 ; 2,61]$, тест Уайта: $\chi 2$ расчет. $=0,93, \chi 2$ крит. $=3,84$.

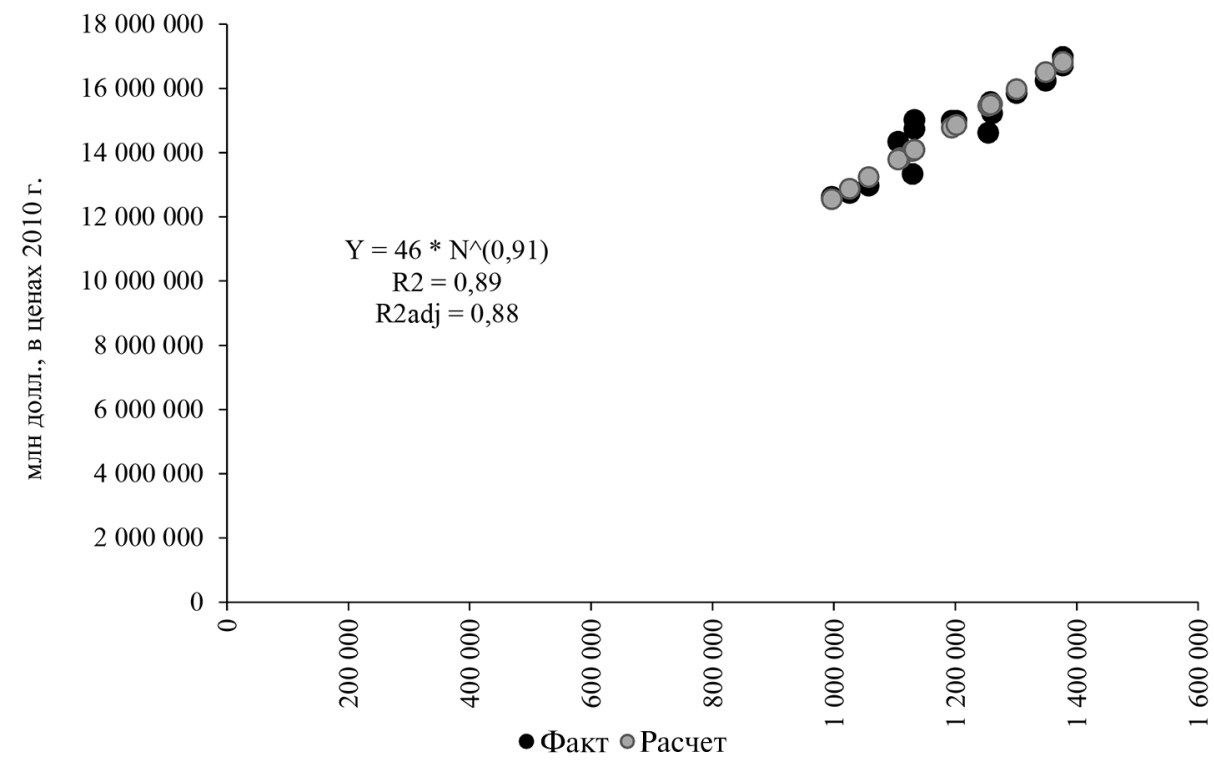

Рис. 5. Валовой внутренний продукт США и численность новаторов, 2000-2017 22.*

Источник: составлено автором по [5; 8].

* Статистики модели: $F$-критерий $=135,2, D$-Wрасчет. $=1,6 €[1,38 ; 2,61]$, тест Уайта: $\chi 2$ расчет. $=0,76, \chi^{2}$ крит. $=3,84$. 


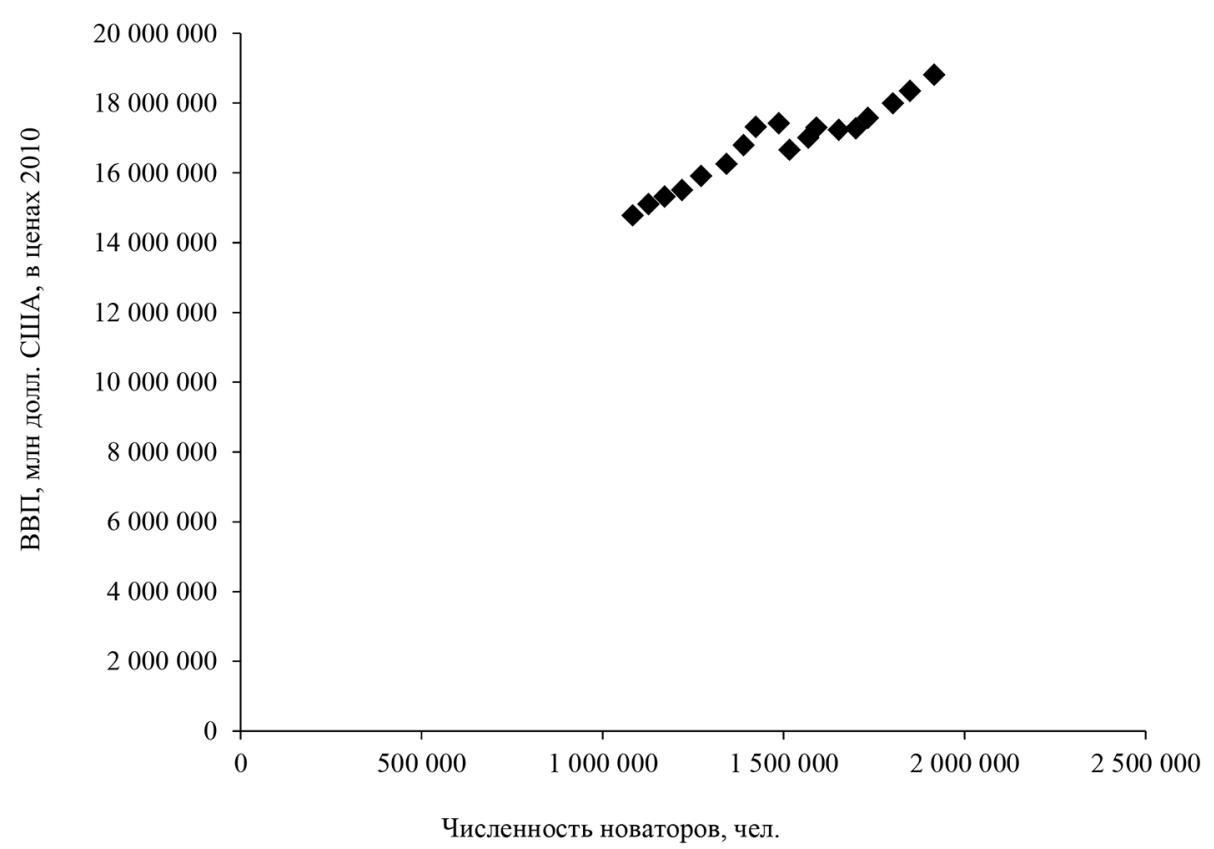

Рис 6. Валовой внутренний продукт ЕС и численность новаторов, 2000-2017 г2.

Источник: составлено автором по [5; 8].

Показательна зависимость темпа роста валового внутреннего продукта в США, России и Китае (cм. pис. 7-9) от удельного веса числа фирм-новаторов в общем числе работающих фирм. В США с ростом удельного веса фирм-новаторов (см. рис. 7) темп роста ВВП несколько увеличивается при дальнейшем росте удельного веса фирм-новаторов немного понижается. В Китае имеется особая ситуация (см. рис. 9), когда с ростом доли числа фирм-новаторов темп роста понижался, оставаясь самым большим среди стран - лидеров экономического развития. В России (см. рис. 8) увеличение удельного веса фирм-новаторов имеет слабую положительную связь с темпом роста ВВП. Наблюдалось снижение числа фирм-новаторов и снижение темпа роста на рассмотренном отрезке времени.

В связи с отмеченными связями, по всей видимости, в Китае перегрев экономики был вызван инновационной динамикой, что и замедлило темп роста (см рис. 9). Причем в отдельные годы китайское правительство специально предпринимало действия по торможению бурного роста, т.к. проблемы с ликвидностью компаний могли привести к перегреву и кризису. Но потребность в ликвидности была вызвана как раз тем, что расширялась инновационная деятельность, требующая добавочных ресурсов. В России стагнатно-рецессионное (с формальным ростом) развитие 2012-2018 гг. характеризовалось как медленным темпом роста, так и снижением инновационной активности, что вполне объясняет полученную связь параметров (см. рис. 8). Американская экономика, показывающая более или менее стабильное на фоне других стран число фирм-новаторов и консерваторов, обнаружила не столь рельефную 
связь темпа роста ВВП и удельного веса фирм-новаторов, хотя американская экономика характеризуется самым высоким удельным весом фирм-новаторов - более трети. Увеличение доли фирм-новаторов на $4 \%$ не дает значительного увеличения темпа роста, который остается на уровне $1,5-2,0 \%$ (см. рис. 7).

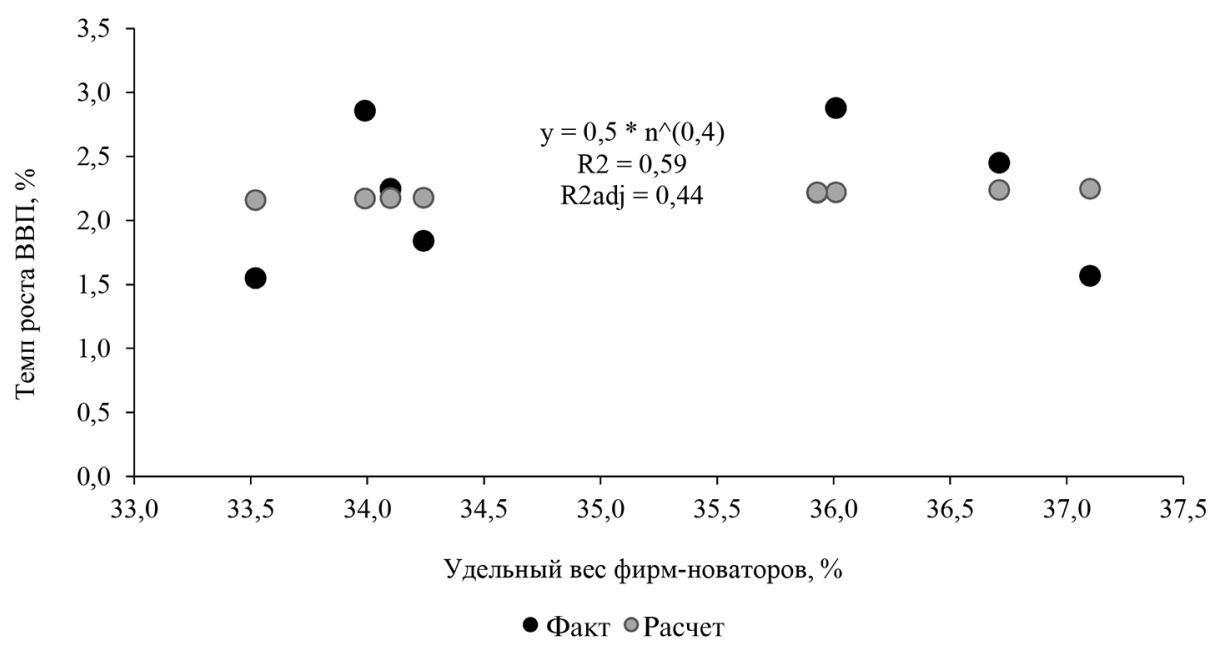

Рис. 7. Темп роста ВВП и удельный вес фирм-новаторов США, 2011-2018 г2.*

Источник: составлено автором по [6; 7].

* Статистики модели: $F$-критерий $=6,7, D$-Wрасчет. $=2,0 €[1,91 ; 2,20]$, тест Уайта: $\chi 2$ расчет. $=1,98, \chi 2$ крит. $=3,84$.

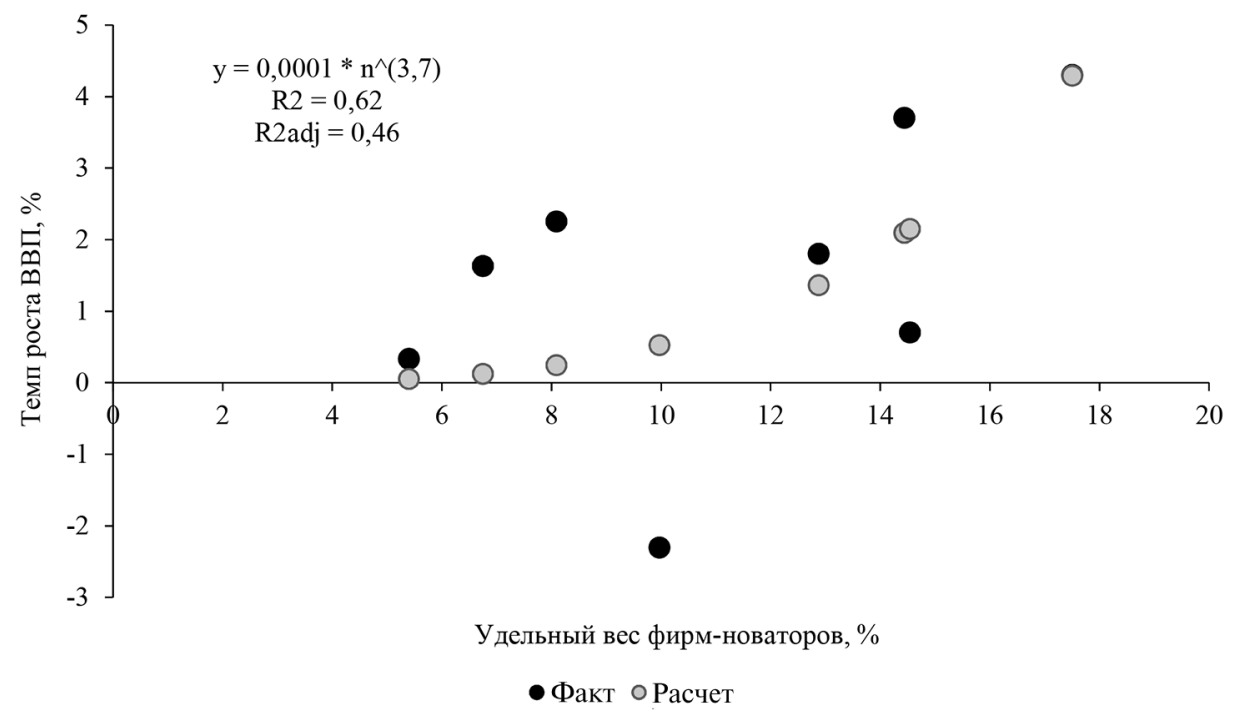

Рис. 8. Темп роста ВВП и удельный вес фирм-новаторов России, 2011-2018 22.*

Источник: составлено автором по [6;7].

* Статистики модели: $F$-критерий $=6,8, D$-Wрасчет. $=1,97 €[1,91 ; 2,20]$, тест Уайта: $\chi 2$ расчет. $=3,79, \chi 2$ крит. $=3,84$. 


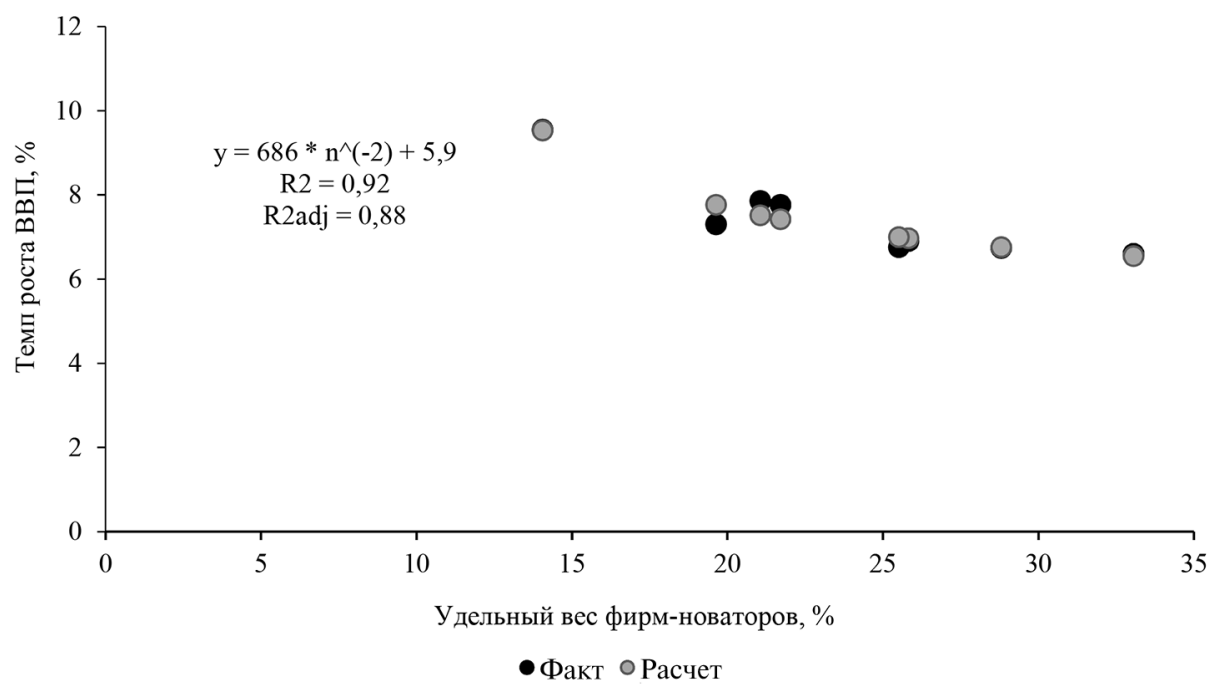

Рис. 9. Темп роста ВВП и удельный вес фирм-новаторов Китая, 2011-2018 г2.*

Источник: составлено автором по [6; 7].

* Статистики модели: $F$-критерий $=59,8, D$-Wрасчет. $=2,05 €[1,91 ; 2,20]$, тест Уайта: $\chi^{2}$ расчет. $=2,58, \chi 2$ крит. $=3,84$.

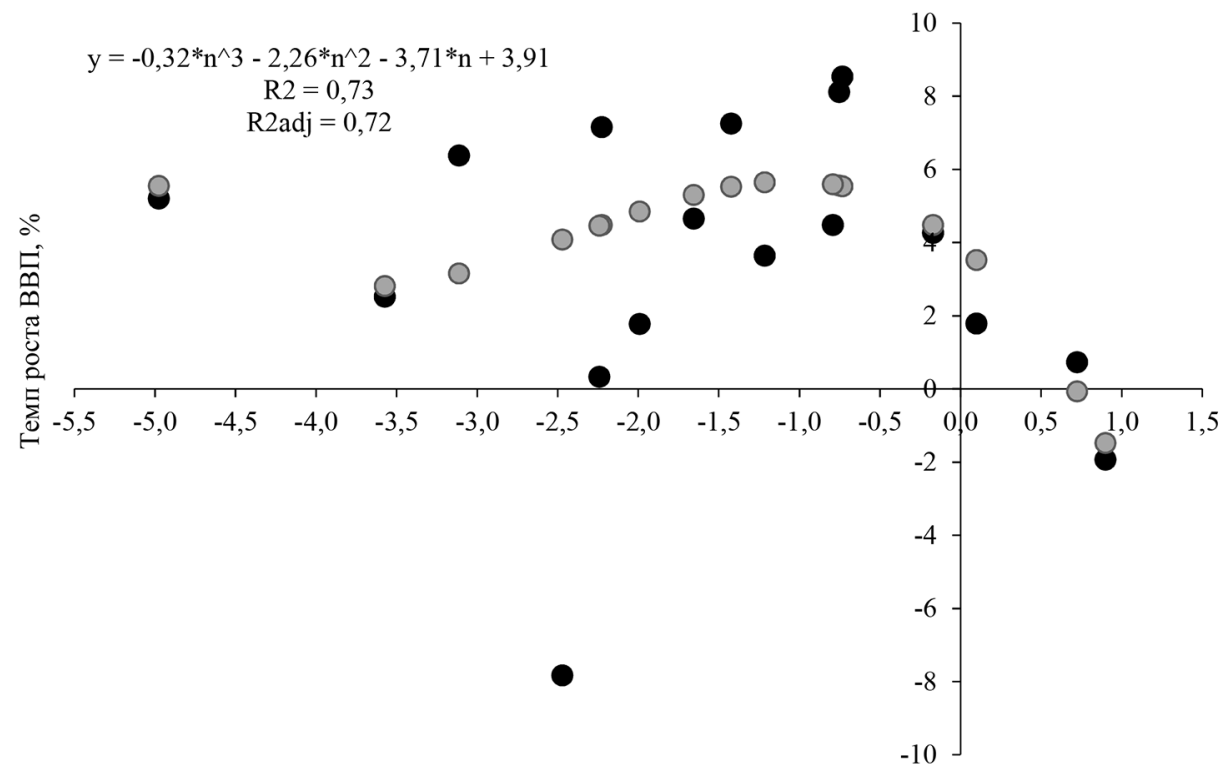

Темп роста численности новаторов, \%

-Факт О Расчет

Рис. 10. Темп роста ВВП и темп роста иисла агентов-новаторов в России, 2001-2017 22.*

Источник: составлено автором по [5; 8].

* Статистики модели по России: $F$-критерий $=7,6, D$-Wрасчет. $=1,9 \in[1,38 ; 2,62]$, тест Уайта: $\chi^{2}$ расчет. $=1,98, \chi^{2}$ крит. $=3,84$. 


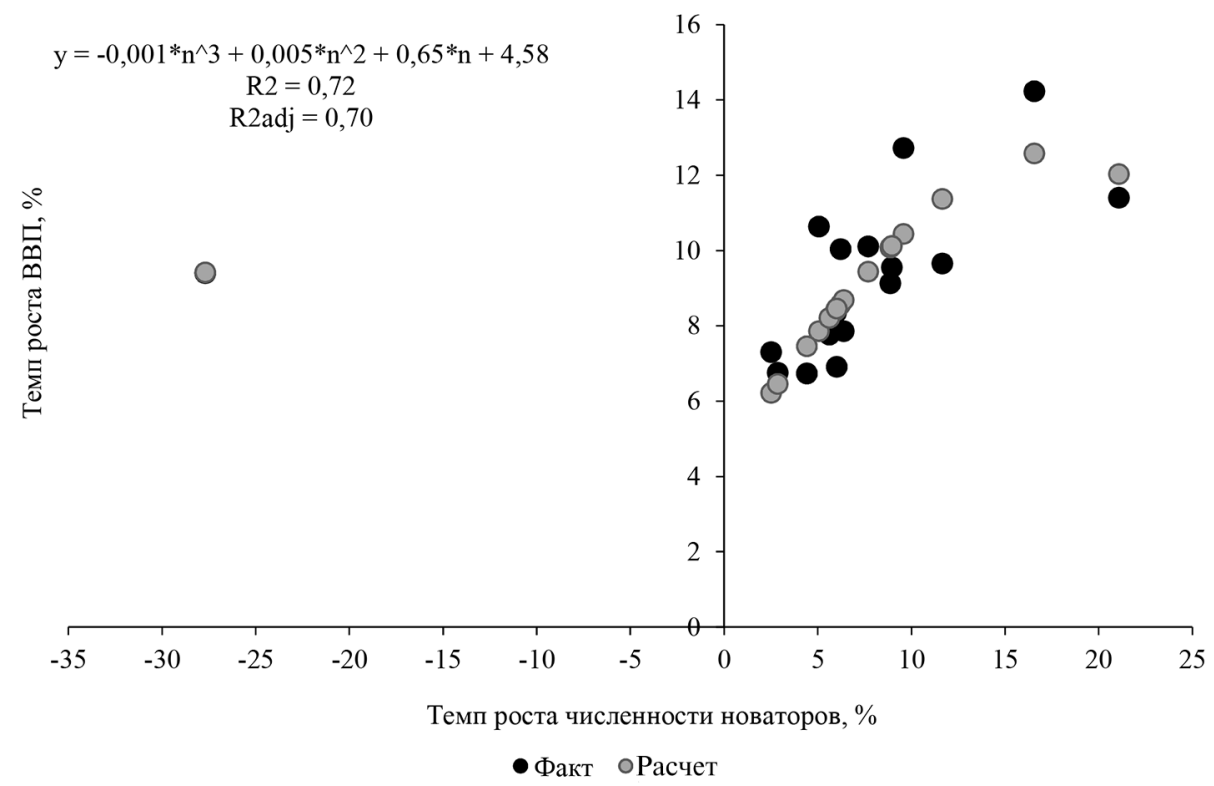

Рис. 11. Темп роста ВВП и темп роста числа агентов-новаторов в Китае, 2001-2017 22.*

Источник: составлено автором по [5; 8].

* Статистики модели по Китаю: $F$-критерий $=38,6, D$-Wрасчет. $=2,2 €[1,38 ; 2,62]$, тест Уайта: $\chi 2$ расчет. $=2,38, \chi 2$ крит. $=3,84$.

Связь темпа роста ВВП и числа агентов-новаторов в России, Китае, США и Европейском союзе показана на рисунках 10-13, где подобраны эконометрические модели. Нужно отметить, что темп роста китайской экономики весьма зависим от темпа роста числа агентовноваторов (cм. puc. 11). В российской экономике (см. рис. 10) наблюдался отрицательный темп роста агентов-новаторов, т.е. число этих агентов сокращалось. Причем снижение сокращения сопровождалось понижением и темпа роста ВВП, увеличение темпа роста числа агентовноваторов - увеличивало темп роста ВВП. Хотя связь для российской экономики двух темпов (темпа роста ВВП и темпа роста агентов новаторов) положительная, но она весьма слабая.

Для американской экономики и ЕС (см. puc. 12, 13) увеличение темпа роста числа агентов-новаторов в среднем немного замедляет темп экономического роста. Для США можно предположить, что причина этого в значительной доле фирм-новаторов и агентов-новаторов, для ЕС число агентов-новаторов еще больше, чем в США, в связи с чем ускорение роста числа этих агентов в силу конкуренции между ними может замедлять темп роста ВВП. Для Китая связь темпа роста ВВП и удельного веса фирм-новаторов и темпа роста ВВП с темпом роста числа агентов-новаторов противоположная. Темп роста ВВП Китая понижался с увеличением доли фирм-новаторов и при снижении темпа роста числа агентов-новаторов. Последний процесс связан с определенным насыщением в области подготовки исследователей, образованных кадров, которые учитываются как агенты-новаторы. Вместе с тем, судя по подо- 
бранной эконометрической модели, обратная связь также присутствует, что увеличение темпа роста агентов-новаторов будет сопровождаться ростом китайской экономики (см. pис. 4). Отметим, что китайская модель инновационной динамики кардинально отличается от того, что видно по другим рассмотренным здесь странам.

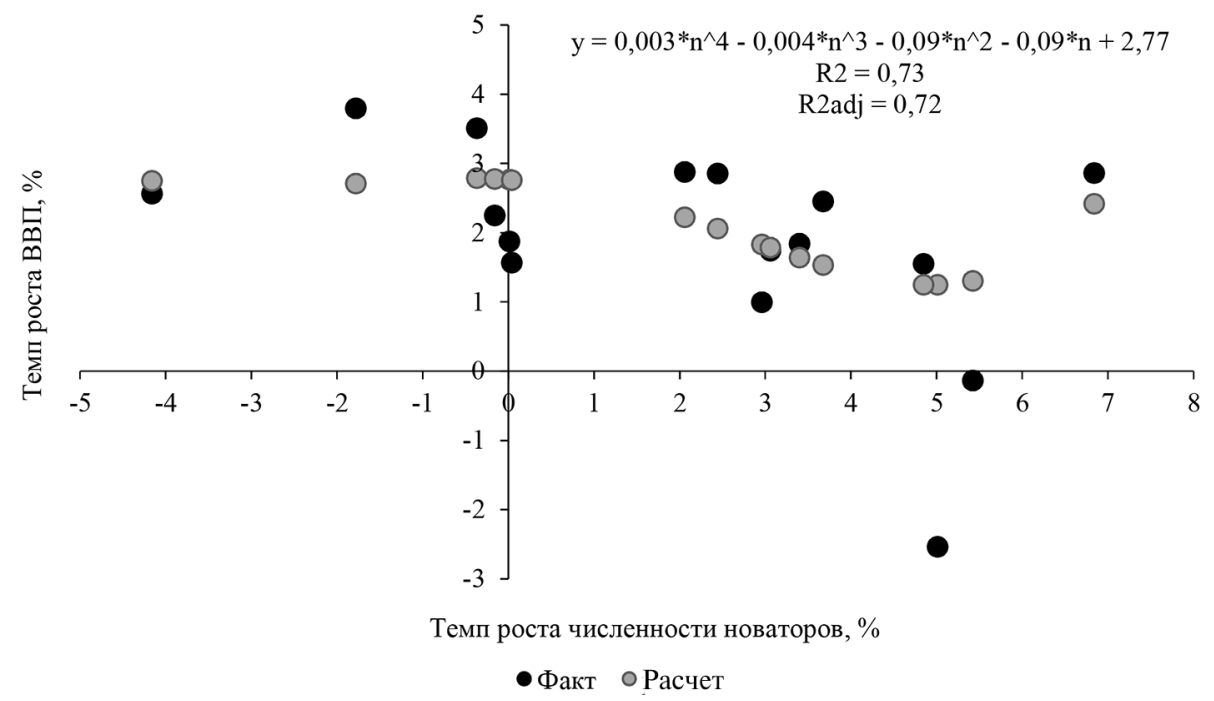

Рис. 12. Темп роста ВВП и темп роста числа агентов-новаторов в США, 2001-2016 22.*

Источник: составлено автором по [5; 8].

* Статистики модели по США: $F$-критерий $=9,7, D$-Wрасчет. $=1,4 \in[1,37 ; 2,63]$, тест Уайта: $\chi 2$ расчет. $=3,55, \chi^{2}$ крит. $=3,84$.

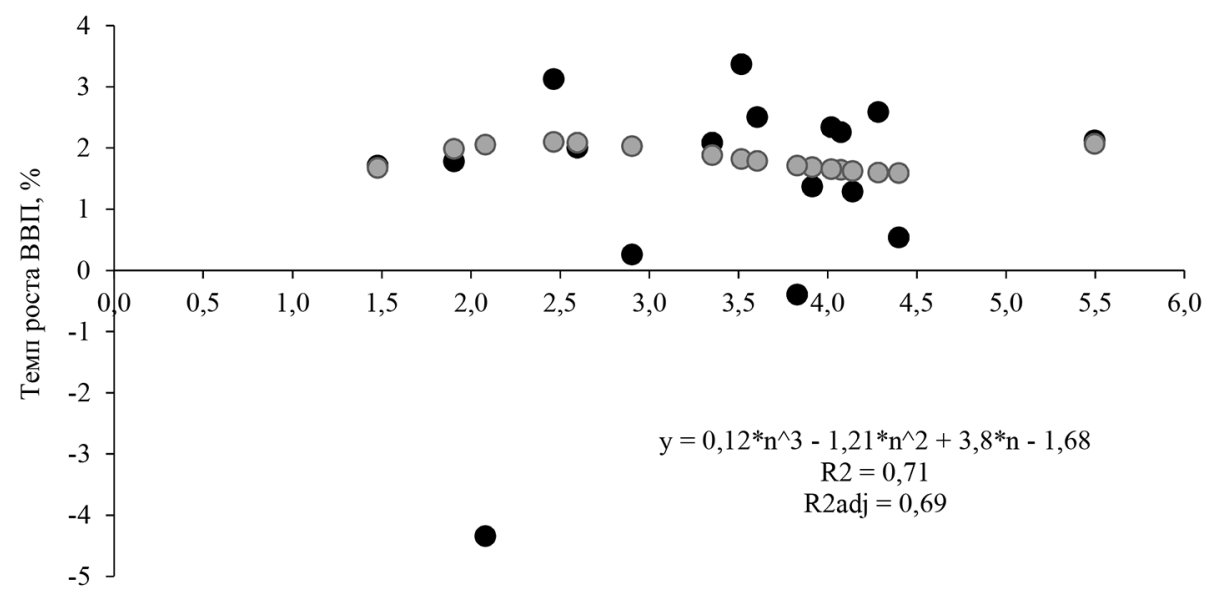

Темп роста численности новаторов, \%

$$
\text { - Факт оРасчет }
$$

Рис 13. Темп роста ВВП и темп роста иисла агентов-новаторов в ЕС, 2001-2017 г2.*

Источник: составлено автором по [5; 8].

* Статистики модели по ЕС: $F$-критерий $=10,3, D$-Wрасчет. $=1,7 \in[1,38 ; 2,62]$, тест Уайта: $\chi^{2}$ расчет. $=2,85, \chi 2$ крит. $=3,84$. 
Таким образом, инновационная динамика, оцениваемая по изменению числа агентов-новаторов и фирм-новаторов, по-разному влияет на темп роста и экономическое развитие в каждой стране. Это влияние зависит от исходного числа агентов-новаторов и фирм-новаторов, относительном доминировании новаторской или консервативной модели поведения, структуры этих агентов и образуемых ими рынков. Кроме того, влияет и оформившаяся (сильная) или несформированная (слабая) связь темпа экономического роста и темпа роста числа агентовноваторов, удельного веса фирм-новаторов или консерваторов. Причем здесь анализировались связи без учета качества и структур полученных инновационных результатов, что само по себе может сказать о многом, начиная от системы образования и подготовки кадров до масштаба и качества содержания проводимых научных исследований фундаментального и прикладного характера.

$$
* \quad * \quad *
$$

Сформулируем основные выводы проведенного исследования.

Несмотря на то, что они получены на материале динамики макроэкономики для отдельных стран, их применимость вполне обоснована на уровне субъектов РФ при реализации региональной политики инновационного развития. Учет состояния фирм, числа фирм-новаторов, их динамики является необходимым условием для выстраивания региональной политики экономического роста инновационного типа. Причем текущая эффективность на микроуровне (фирм) предопределяет их возможности и влияние на инновационную динамику. Тем самым налицо связное рассмотрение процессов на макро- и микроуровне, что пока слабо учитывается в рамках региональных инструментов развития в России, но показывает наличие такой связи на представленном материале в других странах.

Проблемы формирования инновационной динамики пронизывают организацию соответствующих взаимосвязанных мер на микро- и макроуровне, влияющих по появление новаторов - отдельных агентов и организаций. Согласно принятой в России системе учета, и число агентов-новаторов, и фирм-новаторов сокращалось, осуществляемые налоговые изменения никак не способствовали решению задачи стимулирования инноваций, т.к. не осуществлялся анализ чувствительности инноваций различных типов к этим изменениям. Классическая эффективность может не уменьшаться даже при повышении налогов, однако важно то, как изменяются иные параметры - общие затраты (заработная плата и материальные затраты), прибыль, которая в значительной степени зависит от условий, формируемых на рынке.

Инновационная динамика связана с темпом экономического роста, поскольку число новаторов, как агентов, так и фирм, зависит от эффективности инновационной деятельности, а динамика ВВП зависит от числа новаторов или фирм-новаторов, что было показано на эмпирических данных в ряде стран, лидирующих по инновационному развитию, т.е. от структуры рынка (новаторы-консерваторы) и динамизма фирм 
[17]. Тем самым стимулы инновационной деятельности и ее эффективность, структура рынка, подготовленность институтов будут влиять на инновационную динамику и на темп роста. Способности фирм реструктурировать свои ресурсы и создавать новые, а также осуществлять «структурный выбор» становятся методом обеспечения эффективности инноваций [18; 19].

Подобранные эконометрические модели связи ВВП и числа новаторов, темпа роста ВВП и темпа роста числа новаторов, а также темпа роста и удельного веса фирм-новаторов показали, что в разных странах складываются различные по тесноте указанные связи и режимы инновационной динамики в связке с экономическим ростом. Возрастание ВВП происходило при снижении числа новаторов (в других рассмотренных странах при увеличении числа новаторов). Увеличение темпа роста числа агентовноваторов в российской экономике тормозило и увеличивало темп роста на разных временных интервалах. Для китайской экономики торможение темпа роста происходило со снижением темпа роста числа агентовноваторов и ростом доли фирм-новаторов. Американская и европейская экономики характеризовались тем, что с увеличением темпа роста численности новаторов тормозился экономический рост. В этих странах ВВП увеличивался с ростом численности агентов-новаторов.

Таким образом, инновационная динамика довольно чувствительна применительно к российской экономике к институциональным коррекциям. При этом налоговые изменения могут сказаться на численности агентов-новаторов и фирм-новаторов, что скажется и на динамике ВВП. В связи с этим без дополнительных расчетов довольно трудно оценить влияние таких изменений на различные виды инноваций (отдельные виды расчетов вообще не представляется возможным осуществить по причине отсутствия необходимых учетных данных). Поскольку в России реализовывалась политика локальных инноваций, когда в условиях отсутствия системного спроса на новые технологии и иные инновации ресурсы распределяются и направляются по отдельным направлениям инновационного развития, часто не связанным друг с другом, постольку по ним удается получить определенные результаты. Однако существенной связи между динамикой ВВП и инноващиями не наблюдается на рассмотренном отрезке времени. Это требует кардинального пересмотра проводимой экономической политики, нацеленной на стимулирование инновационного развития как в системном, так и региональном измерении.

\section{Список литературы}

1. Castellacci F. A Neo-Schumpeterian Approach to Why Growth Rates Differ // Revue économique. 2004. Vol. 55. N 6. P. 1145-1169.

2. Jati K. A Model of Schumpeterian Dynamics // Applied Economics Letters. 2001. Vol. 8. P. 81-84.

3. Westeren K.I. Innovation: from Schumpeter to the Knowledge Economy // Chapter in Foundations of the Knowledge Economy. London: Edward Elgar Publishing Ltd, 2012. P. 57-74. 
4. Aghion P., Akcigit U., Howitt P. Lessons from Schumpeterian Growth Theory // The American Economic Review. 2015. Vol. 105. N 5. P. 94-99.

5. Всемирный банк. URL: https://data.worldbank.org/indicator/NY.GDP. MKTP. KD.ZG?view=chart (дата обращения: 20.12.2019).

6. Мировой атлас данных. URL: https://knoema.ru/GEMAP2019/globalentrepreneurial-behaviour-monitor?country $=1000240$ \&indicator $=1000250$ (дата обращения: 20.12.2019).

7. Global Entrepreneurship Monitor. URL: https://www.gemconsortium.org/ (дата обращения: 20.12.2019).

8. OECD Data. URL: https://data.oecd.org/rd/researchers.htm (дата обращения: 20.12.2019).

9. Futia C.A. Schumpeterian Competition // The Quarterly Journal of Economics. 1980. Vol. 94. N 4. Р. 675-695.

10. Маевский В.И. Введение в эволюционную макроэкономику. М.: Япония сегодня, 1997. 107 с.

11. Сухарев O.C. Стратегия инновационного развития: агенты и национальные проекты в России // Инвестиции в России. 2019. № 5. С. 3-14.

12. Сухарев О.C. Инновации: динамика, структура, стратегия экспорта и импорта // Металлы Евразии. 2019. № 3. С. 18-21.

13. Kohn M., Scott J. T. Scale Economics in Research and Development: The Schumpeterian Hypothesis // The Journal of Industrial Economics. 1982. Vol. 30. N 3. P. 239-249.

14. Hanusch H., Pyka A. «Manifesto» for Comprehensive Neo-Schumpeterian Economics // History of Economic Ideas. 2007. Vol. 15. N 1. P. 23-41.

15. Глазьев С.Ю. Теория долгосрочного технико-экономического развития. М.: Владар. 1993. 310 с.

16. Сухарев О.С. Теория реструктуризации экономики. М.: Ленанд. 2016. $256 \mathrm{c}$.

17. Aghion P., Ufuk A., Howitt P. The Schumpeterian Growth Paradigm // Annual Review of Economics. 2015. Vol. 7. P. 557-575.

18. Rahmeyer F. Schumpeter, Marshall, and Neo-Schumpeterian Evolutionary Economics: A Critical Stocktaking // Journal of Economics and Statistics. 2013. Vol. 233. N 1. P. 39-64.

19 Sukharev O.S. The Restructuring of the Investment Portfolio: the Risk and Effect of the Emergence of New Combinations. // Quantitative Finance and Economics. 2019. N 3(2). P. 390-411.

\section{EFFICIENCY OF SCIENTIFIC COMPANIES AND FORMATION OF INNOVATIVE DYNAMICS}

Different countries show differing patterns of economic growth and innovation dynamics. For a long time in Russia, it has not been possible to formulate an innovative model of economic growth, a debate about which lasts for more than a decade and government measures are being taken to stimulate innovation and stimulate growth, which do not yet allow us to move on to such the development model. However, this usually happens without taking into account the mode of innovative dynamics that has already taken shape at the current moment, both at the micro level (the effectiveness of science-intensive firms) and at the macro level according to the dynamics of innovative development parameters, in particular, the growth rate of innovative agents, changes in the share of firms innovators. The current effectiveness of the functioning of science-intensive (innovative) firms undoubtedly affects the emergence of innovative firms and the number of agents in the economy. The clarification of such a relationship is important, which will allow us to better outline the outline of the model of the 
innovative type of economic growth. Thus, it was found that in Russia from the analyzed countries (USA, China, EU), the increase in GDP occurred simultaneously with a decrease in the number of innovative agents and the share of innovative companies, and the growth rate decreased with an increase in the growth rate of the number of innovative agents in the studied time interval. This is a conservative model of economic dynamics. The innovative development model assumes a situation where GDP increases with the growth in the number of innovative agents, the growth rate slows down with an increase in the growth rate of the number of innovative agents due to the relatively high share of these agents in the total, which is typical for China. Thus, the formation of an innovative Russian growth model will require changes in the government system of economic policy measures. In particular, it will be necessary to test the impact of changing the law of the relationship between GDP dynamics and the number of firms and innovative agents, as well as the conditions for moving labor resources from old to new industries and training personnel for new industries, take into account restrictions on the effectiveness of science-intensive firms, and introduce a stimulating tax mechanism innovation, and reduce the risks of introducing innovation.

Keywords: conservative firms, the effectiveness of science-intensive organizations, indicators of innovative dynamics, innovating firms, innovations, growth of gross domestic product, region

JEL: C51, O30, O41, O51, O52

Дата поступления - 14.12.2019 г.

\section{СУХАРЕВ Олег Сергеевич}

доктор экономических наук, профессор, главный научный сотрудник; Федеральное государственное бюджетное учреждение науки Институт экономики Российской академии наук / Нахимовский проспект, д. 32 , Москва, 117218.

e-mail: o_sukharev@list.ru

\section{SUKHAREV Oleg S.}

Dr. Sc. (Econ.), Professor, Chief Researcher;

Federal State Budgetary Institution of Science Institute of Economics of the Russian Academy of Sciences / 32, Nakhimovsky Av., Moscow, 117218. e-mail: o_sukharev@list.ru

\section{Для цитирования}

Сухарев О.С. Эффективность наукоемких фирм и формирование инновационной динамики // Федерализм. 2020. № 1. С. 44-65. 